At the Hungarian Academy of Sciences on May 272011 a conference was devoted to the memory of Gyula Rézler/Julius Rezler (1911-2001), one of the founding fathers of Hungarian economic sociology. The note below was presented at this conference. It deals with Rézler's late period, when he acted as an experienced arbitrator and mediator in the U.S.

\title{
JULIUS REZLER, THE ARBITRATOR
}

\section{T. ZANE REEVES ${ }^{l}$}

It is not easy to evaluate someone who has had a major personal and professional impact on one's life, and thus it is for me with Julius Rezler. My task here is to do exactly that and I shall evaluate his contributions to the field of dispute resolution as objectively as I can.

My knowledge of this wise man and friend is obtained from two sources: First, I knew him for the last fifteen years of his life. It was Julius Rezler as my mentor who piqued my interest in labor arbitration and I entered the arbitration profession and eventually the National Academy of Arbitrators. Secondly, I conducted extensive research into the writings of this great man. Following his death I was given all of his arbitration awards, his articles, publications, and of course, his books. Much of this work is contained in the biography published by Gondolat Press and the Julius Rezler Foundation, From Budapest to Albuquerque: the American Life of Julius Rezler (2006).

Based on these two sources, the following principles of dispute resolution were reiterated by Julius throughout his life:

\section{MULTIPLE APPROACHES SHOULD BE APPLIED TO RESOLVE DISPUTES}

Julius believed that an attempt always should be made to settle disputes at the least formal level before applying arbitration. In other words, try mediation before going to arbitration. This is why Julius volunteered as a mediator in the Victim-Offender Program and I worked as a co-mediator

1 T. Zane Reeves, $\mathrm{PhD}$, is professor emeritus at the University of New Mexico, e-mail: tzane@ unm.edu 
with him. It is preferable to resolve disputes so that both parties "win" before trying arbitration, where there always a winner and a loser.

As perspective, very few practicing North American mediators also are arbitrators and only a handful of arbitrators work as mediators. This is because the skills required of a mediator and arbitrator are quite different. One might add that the personalities of arbitrators and mediators are generally diverse as well. Yet Julius thought that it was important to practice both mediation and arbitration techniques and chose the one that would probably resolve the dispute. When Julius received an award from the New Mexico Center for Dispute Resolution in 2001 as a "Global Peacemaker" it was in recognition of his broad approach to dispute resolution.

\section{AN ARBITRATION AWARD IS A TEACHING TOOL}

If you read many of Julius Rezler's arbitration awards, as I have, you will be struck by their clarity and logical flow. Julius often said that he thought one of the purposes of an arbitration award is to explain to the reader and educate the losing party regarding the reasons for the award. The winning party already believes it should have won based on the merits of the case. Julius believed that an arbitrator has an obligation to teach so that the losing person learns from the experience and does not make the same mistakes in the future. The only way the losing party, whether it is management or the union, can change future behavior is to understand why it did not prevail in the arbitrator's view and then make appropriate changes.

\section{ASSESSING THE POTENTIAL FOR EMPLOYEE REFORM AND REHABILITATION}

Again, if you read Julius' Rezler's arbitration awards, you will be impressed with his comprehensive approach in: 1) assessing the underlying causes of the Grievant behavior, 2) and then determining if a discharged employee should be given a "second chance" to correct unacceptable attendance or improve poor performance.

Julius was willing to probe the psychological causes of employee behavior, to a much greater degree than most other arbitrators are willing to do in arbitration awards. Julius would look consider behavioral clues in testimonies of Grievant and Witnesses. For example, Julius offers the following "psychological insights" when writing an award: 
"Sometimes, the exercise of a management prerogative may be tempered with a small dose of human relations skill" (E-Systems, Inc., 1992: 6).

"Hawkins sounded genuinely surprised" (Protectoseal Company, 1986: 5).

“...it is inconceivable that Rubio would ask for Grievant's help to get rid of Bernett. But even if Rubio and Grievant had been on the best of possible terms, it is difficult to believe that a manager would turn to a semi-skilled worker for help to get a fellow manager fired. In this respect, the Grievant's testimony reflects a distorted self-image of his own importance" (ibid).

"While it is perceivable that Grievant might have started urinating in the belief that he was alone, it is difficult to accept that he would start such act while facing a customer. Although such irrational behavior is possible, the arbitrator considers this occurrence improbable. In this connection, it should also be noted that Grievant had delivered products to Superjet for a period of two years. He was familiar with the location of the restroom and had used it in the past. It would have been irrational on the part of the Grievant to urinate in the known presence of a customer when a restroom was available 30 to 40 feet away" (Bon Ton Products, 1982: 6).

"The Arbitrator makes this ruling with considerable reluctance as he is aware that Grievant has a family with four children and he appears to be an articulate young man with above average intelligence" (Amoco Oil, 1978: 12).

As an Arbitrator, Julius Rezler used the "behavioral clues" to determine whether management had just cause for the disciplinary action. He also considered Grievant behavior when deciding whether the employee should be given a "second chance" to change his behavior or performance; is there some indication of employee reform and rehabilitation?

\section{POTENTIAL FOR REFORM AND REHABILITATION}

In essence, Julius Rezler believed discharge could be overturned and the Grievant reinstated if there is evidence that an employee will cease 
unacceptable behavior [reform] and can be restored as a trustworthy employee [rehabilitation]. The following factors indicate that a certain level of potential reform and rehabilitation may be present, and discharge is perhaps premature; if the employee:

Has been free of disciplinary actions for a substantial period prior to the infraction: Julius observed, "Just as the Union will always point out when the employee's record is clean, by the same token, management is also justified to refer to it when the record is no longer clean" (Protosectal 1986: 10).

Was intolerably provoked or threatened by a supervisor: Julius described one incident, "However, with an interval of only two feet between their bodies, his [supervisor's] protruding finger at face level was rightly perceived by Grievant as intolerable. No supervisor has the right to poke with his finger into the face of a supervisee under any pretext. It is humiliating and shows insensitivity on the part of the supervisor" (Indiana Bell Telephone, 1985: 7).

Actively sought or will seek help for his problems: Julius took note, "The Arbitrator also believes that, assuming that his emotional problems were resolved, Grievant may successfully be rehabilitated" (American Federation of Government Employees, Local 1547: 38).

Admitted responsibility for wrongdoing: Julius noted of a Grievant, "...she had no intent to defraud or deceive the Company...” (Caterpillar Tractor, 1983: 6).

Has shown remorse for mistakes: Julius reasoned, "In view of her age and inexperience, the arbitrator believes that she deserves another chance to prove her worth to the Company" (Kroger Company, 1981: 8).

Was cooperative and truthful during the management investigation: Julius concluded, "For these reasons, the arbitrator is convinced that discharge would be a rather harsh penalty for Grievant's offense and a long suspension should be sufficient punishment and reminder for the Grievant to mend his ways in the future" (Amoco Oil, 1977: 12). 
Is committed to a performance/behavior improvement plan: Julius reinstated a Grievant to his previous position on the condition that he "is required to submit himself to the examination of a licensed psychiatrist... reinstatement will only take place upon receipt of an opinion from a psychiatrist that Grievant is fully capable to exercise control over his behavior and to function as an employee" (Caterpillar Tractor Company, 1985: 15).

Assuming that previous disciplinary actions have been tried without success, it may be time to finally discharge the employee, if he exhibits any of the following negative behaviors:

Engages in an ongoing pattern of attendance or performance abuse: Julius noted of one postal clerk, "during his $2 \frac{1}{2}$ years' service with the Employer, he used up his sick leave credits as fast as he earned them. The Employer is not required to put up with such work behavior" (US Postal Service, 1984b: 3).

Continues to blame others for his problems: Julius states, "Accordingly, Respondent did not have any rational motive to take extreme measures against the principals of the School. In the absence of such reason, irrationality of mind remains the only other explanation for the alleged murder plot. Only a paranoid psychopath would commit a mass murder to eliminate his assumed competitors from the field" (Robert J. Kimbrough, 1983: 10).

Has made no effort to seek outside help: As Julius noted regarding the Grievant, "...the conduct of the Grievant demonstrated [he] was clearly irremediable" (Robert J. Kimbrough, 1983: 16).

Was uncooperative and dishonest during pre-disciplinary investigation: Julius was dismayed at the dishonesty of a postal supervisor who would, "...concoct an elaborate story covering two full days in order to blacken the name of a fellow postal employee. It is difficult to assume that the latter would abuse his supervisory power to such an extreme extent. It would require a rather mean person to do so" (US Postal Service, 1984a: 2).

Refuses to commit to any serious change or improvement plan: Julius was unimpressed by a Grievant's “complete lack of self-criticism...despite substantial evidence of less than 
adequate performance in some important areas of his position" (American Federation of Government Employees, 1985: 41).

Most importantly, a Grievant truly does not understand why his behavior is unacceptable: In Whirlpool (1989: 9), Julius noted, "If Grievant is unable to recognize the wrongness of his act, then a corrective disciplinary action would be useless in his case."

Julius Rezler applied principles of human psychology in his arbitration decisions, much like the "First Arbitrator," King Solomon when he was presented with the two women in dispute over who was the real mother. Like Solomon, Julius did not make a decision solely based on legal precedent or interpretation. Julius studied human nature and assessed whether the Grievant was capable of change and rehabilitation. If so, he or she deserved a second chance. This humanistic approach is a key part of his arbitration legacy.

\section{REFERENCES}

Arbitration awards by Julius Rezler:

American Federation of Government Employees, Local \#1395 and Social Security Administration, (1985) FMCS Case \# 83K/00451.

American Federation of Government Employees, Local \#1547 and US Air Force,

Luke Air Force Base, Arizona, (1989) FMCS Case \#87-27252

Amoco Oil Company and International Brotherhood of Teamsters, Local 142, (1978).

Amoco Oil Company and Oil, Chemical, and Atomic Workers International Union, Local 7-1, (1977) FMCS Case \#77K01235.

Bon Ton Products, Inc. and International Brotherhood of Teamsters, Local 703, (1982) FMCS Case \#82K/13805.

Caterpillar Tractor Company and International Association of Machinists and Aerospace Workers, Lodge \#851 (1983), FMCS Case \#82K/26399.

Caterpillar Tractor Company and International Association of Machinists and Aerospace Workers, Lodge \#851 (1985), FMCS Case \#84K/26732.

E-Systems Inc. and United Auto Workers, Local 967 (1992) FMCS Case \#92-12171.

Indiana Bell Telephone Company Inc. and Communication Workers of America, Local 5708, (1985) FMCS Case \#80K/22718,

Kroger Company and United Food and Commercial Workers Union, Local 1696, (1981) FMCS Case \#81K/17408.

Protectoseal Company and International Association of Machinists and Aerospace

Workers, District \#8, (1986) FMCS Case \#85K/16854.

Robert J. Kimbrough by the Board of Education of the City of Chicago, (1983) Board 
Reports \# 79-172-7, 82-204-10.

US Postal Service and National Association of Letter Carriers, Branch \#11 (1984a) Case \# C1N-4D-D 25379.

US Postal Service and American Postal Workers Union, Greater Kansas City Local, (1984b), Case \#C1T-4H-D 26767.

Whirlpool Corporation, La Porte Division, and United Automobile, Aerospace, and Agricultural Implement Workers of America, Local \#1172, (1989) FMCS Case \#88-1273. 